九州大学学術情報リポジトリ

Kyushu University Institutional Repository

\title{
A rare alpheid shrimp Aretopsis amabilis De Man from the Ryukyu Islands (Decapoda, Crustacea)
}

Miyake, Sadayoshi

Zoological Laboratory, Department of Agriculture, Kyushu University

Miya, Yasuhiko

Zoological Laboratory, Department of Agriculture, Kyushu University

https://doi.org/10.5109/22760

出版情報: 九州大学大学院農学研究院紀要. 14 (2)，pp.267-273，1967-03. Kyushu University バージョン：

権利関係 : 
Journal of the Faculty of Agriculture, Kyushu University, Vol. 14, No. 2 March 30, 1967

\title{
A rare alpheid shrimp Aretopsis amabilis De Man from the Ryukyu Islands (Decapoda, Crustacea) ${ }^{1)}$
}

\author{
Sadayoshi Mryake and Yasuhiko Mrya
}

In the course of the study on alpheid shrimps deposited in the collection of the Zoological Laboratory, Faculty of Agriculture, Kyushu University (ZLKU) we found a rare species belonging to Aretopsis De Man, in which only two species have hitherto been known. The typespecies is Aretopsis amabilis De Man (1910) based on a single specimen collected at East Borneo and has not been recorded since then. Its rediscovery is therefore a matter of considerable interest. The other species is $A$. aegyptiaca Ramadan only known from the northern Red Sea (Ramadan, 1936; Holthuis, 1958).

The present specimen (an ovigerous female) was found at a coral flat reef, Okinawa-jima, and this species is new to the fauna of the Ryukyu Islands so far as we know.

We wish to express our hearty thanks to Mr. Hisakatsu Minei of our laboratory for his kindness to offer us the valuable material.

\section{Aretopsis amabilis De Man, 1910}

(Figs. 1, 2)

Aretopsis amabilis De Man, 1910, p. 311-Pulu Kaniungan-Ketjil, East Borneo.

Aretopsis amabilis: De Man, 1911, p. 171-No new locality.

Aretopsis amabilis: De Man, 1915, pl. 4, fig. 14-No new locality.

Description. The body is medium-sized (carapace length $6.0 \mathrm{~mm}$, total length $18.5 \mathrm{~mm}$ ), polished and stout (Fig. 1). The rostrum is equilaterally triangular with a blunt dorsal carina and a broad ventral lamella; the blunt rostral apex slightly exceeds the tip of the first antennular segment (Fig. 2, A, B); the orbitorostral margin is smooth without the

1) Contributions from the Zoological Laboratory, Faculty of Agriculture, Kyushu University, No. 357. 
supra-and extra-corneal teeth, concealing the posterior half of the cornea; the infracorneal tooth is obtuse and the pterygostomial margin is rounded.

The antennular peduncle is robust; the third segment is as long as the proximal two segments together; the stylocerite is robust, exceeding the rostral apex; the outer antennular flagellum is composed of seven joints in the proximal portion before bifurcation.

The basicerite of the antenna has two heavy teeth, i. e. a rounded lateral and a blunt inferior one; the carpocerite is broad, extending beyond the tip of the antennular peduncle; the scaphocerite has a strong acute lateral spine and the anterior margin of the lamella hardly reaches to the tip of the carpocerite.

The third maxilliped exceeds the tip of the antennular peduncle (Fig. $2, \mathrm{C})$; the ultimate segment bears no spine on the top, the penultimate one is shorter than half as long as the ultimate, and the antepenultimate one is 1.5 times of the ultimate; the upper distal margin of the antepenultimate segment is protuberant; the exopod slightly exceeds the tip of the antepenultimate segment.

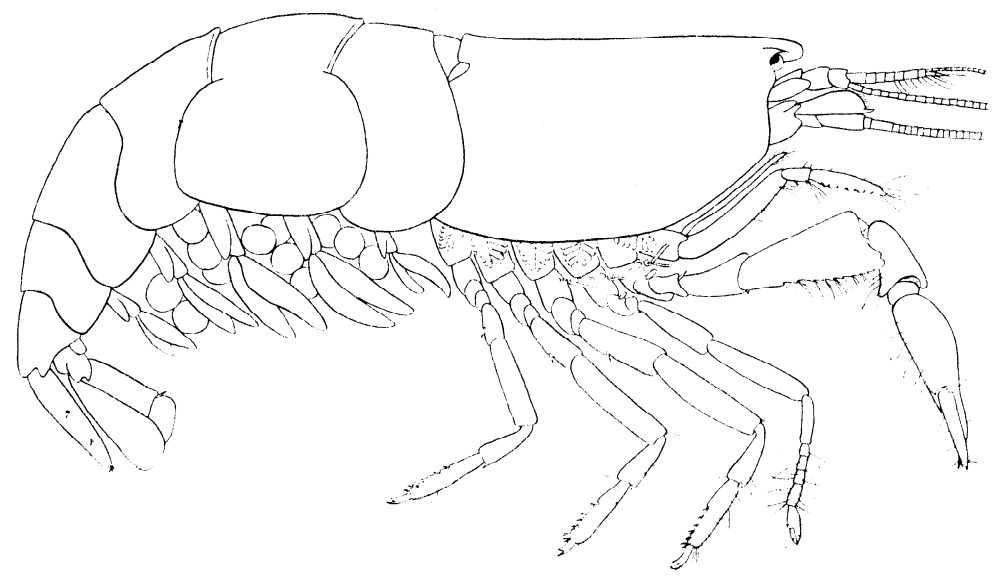

Fig. 1. Aretopsis amabilis De Man, ovigerous female, $\times 5.8$.

The first and second pereiopods are provided with a rudimentary exopod. The first pereiopods are asymmetrical and have chelae twisted outward, exceeding beyond the scaphocerite by the length of the chela in the large cheliped and by the length of the carpus and chela in the small one.

In the large cheliped of the first pereiopods the fingers are sharp pointed and slightly shorter than two-thirds the length of the palm; the cutting edge of the movable finger is serrated in the distal half, armed with a blunt heavy tooth at the middle, and has a shallow con- 
cavity in the proximal half (Fig. 2, D, E); the cutting edge of the immovable finger has a crest ending in eight blunt teeth distally and bears a massive rounded tooth separated by a distinct deep interval from the crest. The palm is rectangular in lateral view and strongly compressed; the height (breadth) is three-quarters of the length and the thickness two-fifths of the length; the upper margin (the lower margin in Fig. 2, D) of the palm is convex, furnished with an indistinct groove; the lower margin (the upper margin) is furnished with the sharp carina which is slightly serrated distally (four indistinct teeth) and ends at the base of the immovable finger. The carpus is cup-shaped and one-third as long as the palm; the outer surface of this segment is distally overhanging the base of the palm as a broad and flat projection; the inner surface has a broad ridge inferiorly. The merus is two-fifths the length of the palm and semicircular in cross section; the outer distal margin is separated into two lobes by a notch at the middle, and the lower lobe of them stretches forward, ending in two rounded tops; the inner surface is smooth, bearing no tooth near the base of the lower margin; in ventral view the lower surface is triangular, swollen and broadly concave distally. The ischium is shorter than one-fifth the length of the palm and broader than long, the lower inner margin projects as a triangular process which is observed in lateral view as a short tooth.

The small cheliped of the first pereiopods is similar to the large one, while it is slenderer than the latter and is sparsely hairy on the lower margins of the chela, carpus and merus (Fig. 2, F, G). 'The fingers are two-thirds the length of the palm, the tips of them are crossing together; the cutting edge of the movable finger is serrated throughout the length, while in the immovable one it is entire, sparsely hairy, without any crenulation. The palm is twice as long as broad and twice as long as thick; the upper margin (lower margin in Fig. 2, F) is convex without any groove and the lower margin (upper margin) has an inconspicuous carina distally ending at the base of the immovable finger. The carpus is two-thirds the length of the palm and the merus as long as the palm; the outer lower margin of the merus is indented and bristled. The ischium is somewhat shorter than the palm, bearing a small spine on the middle of the superior margin; the lower distal margin of the inner surface is pointed as a small tooth.

The second pereiopod extends beyond the distal end of the antennular peduncle by the chela and carpus; the carpus is subdivided into five joints, the proximal (first) one of which is slightly shorter than other four joints together; the second, third and fourth are subequal and each of them is half as long as the fifth joint.

The third pereiopod reaches beyond the tip of the third maxilliped 


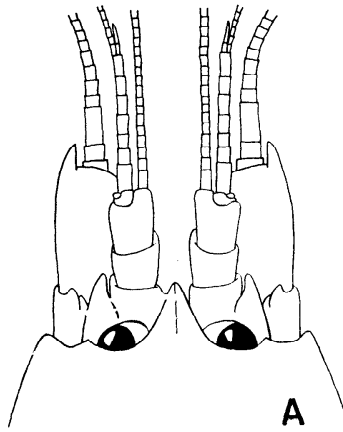

A

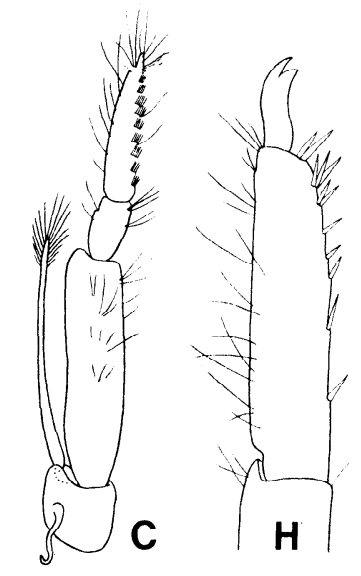

B
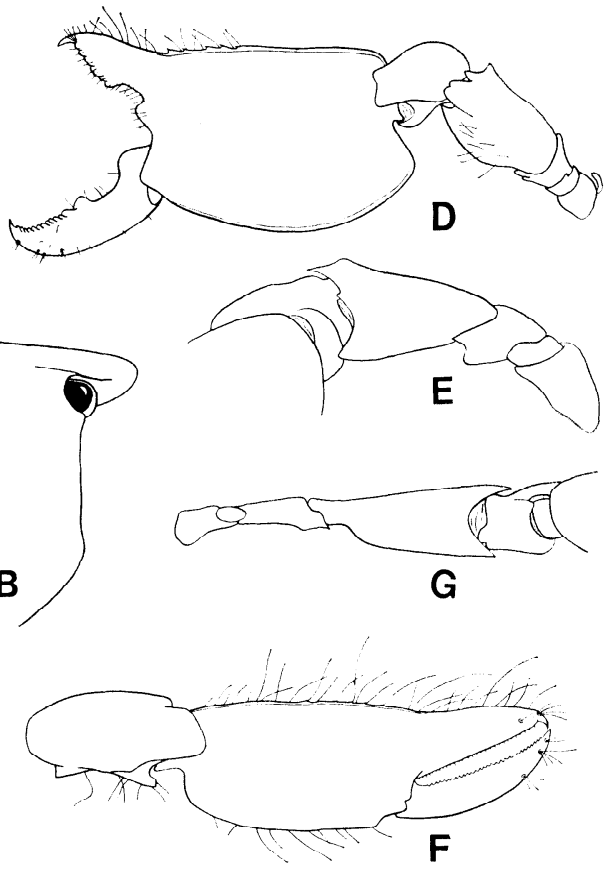

F
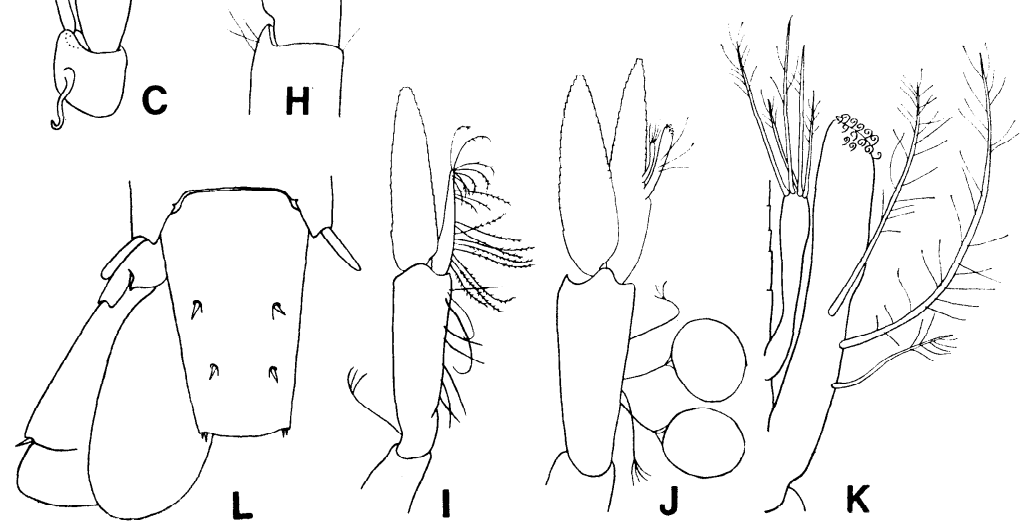

Fig. 2. Aretopsis amabilis De Man.

A, Anterior part of body in dorsal view, $\times 11.7$; $B$, anterior part of carapace in lateral view, $\times 11.7 ; \quad C$, third maxilliped, $\times 11.7 ; \mathrm{D}$, large cheliped (first pereiopod) in lateral view, $\times 5.8$; E, basal part of large cheliped in ventral view, $\times 8.8 ; \quad F$, chela and carpus of small cheliped (first pereiopod) in lateral view, $\times 13.0 ; \mathrm{G}$, basal part of small cheliped in ventral view, $\times 8.8 ; \mathrm{H}$, dactylus and propodus of third pereiopod, $\times 24.9$; $\mathrm{I}$, first pleopod, $\times 11.7$; J, second pleopod, $\times 11.7 ; \mathrm{K}$, appendix interna and appendix masculina of second pleopod, $\times 60.0$; L, telson and left uropod in dorsal view, $\times 11.7$. 
by the dactylus and propodus; the dactylus is biunguiculate, there is a stout lower hook and a sharp pointed upper hook which is slenderer and longer than the lower one (Fig. 2, H) ; the propodus is 4.5 times as long as broad, bearing a dozen of movable spines on the lower margin; the upper distal corner of the carpus is prominent; the merus is 4.3 times as long as broad, unarmed; the ischium is armed with a small movable spine on the lower margin.

The following two pereiopods are similar to the third one in shape; the fourth pereiopod exceeds the tip of the third maxilliped by the tip of the dactylus, the fifth one is far beyond the anterior margin of the carapace by the tip of the dactylus.

Table 1. Branchial formula.

\begin{tabular}{lcccccccc}
\hline & I & II & III & IV & V & VI & VII & VIII \\
\hline Pleurobranchs & - & - & - & 1 & 1 & 1 & 1 & 1 \\
Arthrobranchs & - & - & - & - & - & - & - & - \\
Podobranchs & - & - & - & - & - & - & - & - \\
Epipods ${ }^{1}$ & 1 & 1 & 1 & 1 & 1 & - & - & - \\
Setobranchs 2$)$ & - & - & - & 1 & 1 & 1 & - & - \\
Exopods & 1 & 1 & 1 & $1^{3)}$ & $1^{3)}$ & - & - & - \\
\hline
\end{tabular}

1,2) The epipod (the hook-like mastigobranch) and the small setiferous lobe-like setobranch refer to the epipod $\alpha$ and $\beta$ applied by Coutière (1899, pp. 268-286), respectively.

3) This is a rudimentary exopod.

The first five abdominal segments are smooth with rounded pleura, while in the sixth segment the posterolateral angle of the tergum is obtusely pointed and the posterior margin of the pleuron articulated.

The endopod of the first pleopod is slender, fringed with long plumose hairs on the inner margin and somewhat longer than half of the exopod (Fig. 2, I). Each endopod of the second pair of the pleopods of this ovigerous female has two appendices as in the males of general Caridea; the inner appendix is stout, furnished with some hooks on the subterminal and three long plumose hairs on the proximal half of it, reaching to the distal third of the endopod; the outer appendix is slender, furnished with five rather short plumose hairs on the top, failing to reach to the top of the inner appendix (Fig. 2, J, K)

The uropod is rectangular, the diaeresis of the exopod comes to an end at the middle and bears with a short spine on the distal corner.

The telson is truncate, 2.8 times as long as its posterior margin and shorter than the uropod (Fig. 2, L); the anal tubercles are conspicuous; the margin between the two pairs of posterolateral spines is gently rounded, fringed with long plumose setae; two pairs of dorsal spines are present, the proximal pair is situated at the middle of the 
telson and the distal one at the distal fourth.

Material examined. 1 ovig. 우, ZLKU No. 3507, Naminoue, coral flat reef, Naha City, Okinawa-jima, Ryukyu Islands, May 23, 1959, H. Minei leg.

Remarks. The present intact specimen, an ovigerous female, agrees rather well with De Man's description and figures, though some differences may be observed. This specimen ( $18.5 \mathrm{~mm}$ in total length) is considerably larger than De Man's type ( $11 \mathrm{~mm}$ in total length); the rostrum is two-thirds as high as long with the rounded tip and higher than that of the type specimen; the stylocerite exceeds the tip of the first antennular peduncle, but in the type the former much exceeds the latter; the telson is 2.8 times as long as broad at the posterior portion instead of 3.5 times as described by De Man; the telson bears two pairs of posterolateral spines, the inner pair of which is slenderer and shorter than that of the type specimen; the anal tubercles of this specimen is conspicuous, while in the type specimen they are "probably wanting."

The present material from a coral flat reef of Okinawa-jima, the Ryukyu Islands is the second to become known of Aretopsis amabilis.

The rediscovery of this species apparently lost sight of for more than fifty years is a point of some interest.

In addition, an examination of the second pleopods reveals that each of the endopods has two appendices, i. e. a stout appendix interna and a slender appendix masculina. The same case is also found in three females ( 1 ovig. 우, 2 우우) of Athanas indicus (Coutière) ${ }^{1)}$ in the collection $^{2)}$ of the Zoological Laboratory of the Kyushu University, and they have the appendix interna and the appendix masculina which is diminutive and less setous than that of the male. Generally the shrimps belonging to Caridea are provided with two appendices in the mature male and with the appendix interna only in the mature female. The presence or absence of these appendices is regarded as one of the good criteria of the sex.

It seems advisable for the present to consider that the presence of both appendix interna and appendix masculina in this ovigerous female

1) According to Banner and Banner (1960, pp. 134-135) Arete Stimpson must be regarded as a synonym of Athanas Leach.

2) This material will be discussed in our future paper dealing with this genus from Japan. The localities of these specimens are as follows: 1 우, ZLKU No. 2467, collected from Ngadarák Reef, Palau Islands; 1 ovig. 우, ZLKU No. 3321, Ishigaki-jima, Ryukyu Islands; 1 ð, 1 ovig. ㅇ, ZLKU No. 3318, Okinawa-jima, Ryukyu Islands; 1 ð, 1 우, ZLKU No. 3220, Amakusa, western Kyushu; 1 ๙, ZLKU No. 2355, Okino-shima, northern Kyushu ; 2 ð̋, ZLKU No. 3322, Shirahama, Wakayama Pref. 
may be an aberrant form as well as found in some females of Athanas indicus.

\section{References}

Banner, A. H. and D. M. Banner 1960. Contributions to the knowledge of the alpheid shrimp of the Pacific Ocean. Part 5. The Indo-Pacific members of the genus Athanas. Pacific Sci., vol. 14, no. 2, pp. 129-155, figs. 1-6.

Coutière, H. 1899. Les "Alpheidae," morphologie externe et interne, formes larvaires, bionomie. Ann. Sci. nat. Zool., ser. 8, vol. 9, pp. 1-559, figs. 1-409, pls. 1-6, 1 map.

Holthuis, L. B. 1958. Contributions to the knowledge of the Red Sea. no. 8. Crustacea Decapoda from the northern Red Sea (Gulf of Aqaba and Sinai Peninsula). I. Macrura. Bull. Sea Fisheries Research Station, Haifa, Israel, no. 17, pp.1-40, figs. 1-15.

Man, J. G. De 1910. Diagnoses of new species of macrurous decapod Crustacea from the "Siboga-Expedition," 5. Tijdschr. Ned. Dierk. Vereen, 2, vol. 11, no. 4, pp. 287-319.

Man, J. G. De 1911. The Decapoda of the Siboga Expedition. Part 2. Family Alpheidae. Siboga Exped., Mon. 39a1, pp. 133-465.

Man, J. G. De 1915. The Decapoda of the Siboga Expedition. Supplement to part 2. Family Alpheidae. Siboga Exped., Mon. 39a1, pls. 1-23.

Ramadan, M. M. 1936. Report on a collection of Stomatopoda and Decapoda from Ghardaqa, Red Sea. Bull. Fac. Sci. Egypt. Univ., no. 6, pp. 1-43, pls. 1, 2. 